Jurnal Gizi Klinik Indonesia

Vol. 16 No. 2, Oktober 2019 (47-57)

ISSN 1693-900X (Print), ISSN 2502-4140 (Online)

Tersedia online di https://jurnal.ugm.ac.id/jgki

DOI: https://doi.org/10.22146/ijcn.43090

\title{
Malnutrisi rumah sakit dan asuhan nutrisi pediatrik di Rumah Sakit Hasan Sadikin Bandung
}

Hospital malnutrition and pediatric nutrition care in Hasan Sadikin Hospital Bandung

Tisnasari Hafsah ${ }^{1}$, Titis Prawitasari², Julistio Tryoga Budhiawan Djais ${ }^{1}$

${ }^{1}$ Rumah Sakit Umum Pusat Dr. Hasan Sadikin/ Fakultas Kedokteran Universitas Padjadjaran, Bandung

${ }^{2}$ Rumah Sakit Umum Pusat Nasional Dr. Cipto Mangunkusumo/ Fakultas Kedokteran Universitas Indonesia, Jakarta

\begin{abstract}
Background: Malnutrition during hospitalization delays the recovery of children with acute or chronic illnesses. The Pediatric Nutrition Care (PNC) can improve nutritional support and reduce the prevalence of hospital malnutrition. Objectives: This study was done to find evidence of hospital malnutrition and to evaluate the nutrition care in pediatric ward of Dr. Hasan Sadikin Hospital, Bandung. Methods: We evaluated malnutrition by comparing body weight change between the first day of admission and at hospital discharge to the length of hospitalization. Screening for malnutrition risk was done using modified Pediatric Yorkhill Malnutrition Screening (mPYMS). Score $\geq 2$ was determined as high risk. The PNC process was evaluated by a focused group discussion with PNC-associated pediatric ward personnel. Results: From February-March 2016, 760 patients were admitted to the pediatric ward, of which 111(14.6\%) were included in the study. An mPYMS score of $\geq 2$ was found in $69(62.2 \%)$ of the patients. During hospitalization, body weight decreased in 23(20.7\%) patients, 10(9.0\%) of whom were defined as hospital malnutrition. Among these, seven had an $m P Y M S$ score $\geq 2$. PNC was performed in patients with an $m P Y M S$ score $\geq 2$ by dietitians who also provided a standardized nutrition care process following American Dietetic Association recommendation. However, a dedicated multidisciplinary PNC team was absent and the nutrition and metabolic disease division was consulted only in a few cases. Performing consistent monitoring and evaluation of PNC was also found to be difficult. Conclusions: Hospital malnutrition may be prevalent among pediatric patients in Dr. Hasan Sadikin Hospital, Bandung. Improving PNC services may reduce this prevalence.
\end{abstract}

KEYWORDS: care; pediatric; nutrition; hospital; malnutrition

\begin{abstract}
ABSTRAK
Latar belakang: Malnutrisi selama perawatan menghambat proses penyembuhan pada anak dengan penyakit akut maupun kronis. Asuhan Nutrisi Pediatrik (ANP) dapat meningkatkan dukungan nutrisi dan menurunkan prevalensi malnutrisi rumah sakit. Tujuan: Penelitian ini dilakukan untuk mengetahui kejadian malnutrisi rumah sakit dan mengevaluasi pelaksanaan ANP di ruang rawat inap anak Rumah Sakit Hasan Sadikin, Bandung. Metode: Kejadian malnutrisi rumah sakit ditentukan dengan membandingkan perubahan berat badan pasien saat masuk dan saat pulang terhadap lamanya perawatan. Skrining risiko malnutrisi dilakukan dengan menggunakan modifikasi Pediatric Yorkhill Malnutrition Screening (mPYMS) dengan kategori berisiko tinggi jika skor lebih dari atau sama dengan 2. Proses ANP dievaluasi menggunakan Focused Group Discussion (FGD) dengan personel ruang rawat anak terkait. Hasil: Pada bulan Februari-Maret 2016, sebanyak 760 pasien dirawat di ruang perawatan anak dan sebanyak 111 anak $(14,6 \%)$ ikut serta dalam penelitian. Skor mPYMS $\geq 2$ ditemukan pada 69 pasien $(62,2 \%)$. Selama perawatan, penurunan berat badan terjadi pada $23(20,7 \%)$ pasien dan $10(9 \%)$ pasien diantaranya memenuhi kriteria malnutrisi rumah sakit. Kelompok yang mengalami malnutrisi rumah sakit, sebanyak 7 anak mempunyai skor mPYMS $\geq 2$. ANP diimplementasikan pada pasien dengan skor mPYMS $\geq 2$ oleh dietisien dengan menggunakan proses asuhan gizi terstandar (PAGT) mengikuti rekomendasi American Dietetic Association. Namun, belum terdapat tim ANP dari berbagai multidisiplin yang saling bekerja sama dan hanya sedikit kasus yang dikonsultasikan kepada dokter divisi nutrisi dan penyakit metabolik. Pelaksanaan monitoring dan evaluasi juga masih sulit dilakukan dengan konsisten. Simpulan: Malnutrisi selama perawatan sering terjadi pada pasien anak di Rumah Sakit Hasan Sadikin Bandung. Peningkatan kualitas pelayanan ANP diperlukan untuk dapat menurunkan prevalensi malnutrisi rumah sakit.
\end{abstract}

KATA KUNCI: asuhan; pediatrik; nutrisi; rumah sakit; malnutrisi

Korespondensi: Tisnasari Hafsah, Rumah Sakit Umum Pusat Hasan Sadikin/Fakultas Kedokteran Universitas Padjadjaran, Jl. Pasteur No. 38, Bandung, Jawa Barat, Indonesia, Telp.087824462138,e-mail: tisnasari_hafsah@yahoo.com

Cara sitasi: Hafsah T, Prawitasari T, Djais JTB. Malnutrisi rumah sakit dan asuhan nutrisi pediatrik di Rumah Sakit Hasan Sadikin Bandung. Jurnal Gizi Klinik Indonesia. 2019;16(2):47-57. doi: 10.22146/ijen.43090 


\section{PENDAHULUAN}

Dukungan nutrisi merupakan bagian yang tidak dapat terpisahkan dari tata laksana perawatan anak di rumah sakit, di samping terapi medis dan asuhan keperawatan. Dukungan nutrisi yang tidak adekuat menyebabkan kekurangan gizi pada anak dengan penyakit akut maupun kronis dan berhubungan dengan komplikasi yang mungkin terjadi, lama perawatan, dan tingginya biaya perawatan $(1,2)$. Hal ini disebabkan kondisi malnutrisi yaitu status gizi pada keadaan kelebihan maupun kekurangan energi, protein, dan nutrisi lain yang menyebabkan gangguan pembentukan jaringan tubuh, fungsi, dan dampak klinis (1).

Malnutrisi rumah sakit (hospital acquired malnutrition) merupakan akibat dari asupan dan kebutuhan gizi yang tidak seimbang selama anak dirawat di rumah sakit (3). Etiologi yang menjadi dasar malnutrisi berkaitan dengan penyakit yang sedang diderita, lingkungan/perilaku, atau keduanya sehingga anak tidak memperoleh asupan gizi yang adekuat (4). Malnutrisi dan kondisi penyakit menjadi penyebab timbal balik satu dengan yang lain. Anak yang mengalami malnutrisi akan mudah jatuh sakit terutama infeksi akibat penurunan daya tahan tubuh dan seringkali proses penyembuhan berlangsung lebih lama. Sementara pada saat anak sakit akut maupun kronis, terjadi proses inflamasi yang menimbulkan pelepasan berbagai sitokin, mediator yang berperan besar pada imunomodulasi dan terlibat dalam etiologi hilangnya berat badan, disfungsi kognitif, anemia, dan kelemahan. Peningkatan sitokin proinflamatori yang berlebihan seperti interleukin-1, interleukin-2, interferon gamma, dan faktor tumor nekrosis alfa diduga merupakan penyebab kaheksia pada pasien dengan penyakit akut $(5,6)$. Dengan demikian, asuhan nutrisi selama perawatan anak yang tidak adekuat akan meningkatkan risiko terjadi malnutrisi sehingga proses penyembuhan menjadi tidak optimal dan waktu perawatan lebih lama. Lama rawat inap di rumah sakit juga merupakan faktor risiko penyebab terjadinya malnutrisi (7).

Prevalensi malnutrisi pada pasien di bangsal perawatan anak cukup tinggi. Hasil survei di Red Cross War Memorial Children's Hospital, Cape Town didapatkan sebanyak 34\% dari 227 anak teridentifikasi malnurisi (8). Studi literature review melaporkan prevalensi malnutrisi akut selama 10 tahun terakhir di negara Jerman, Perancis, UK, dan USA yang bervariasi antara 6,1\% hingga 14\% sedangkan di Turki mencapai 32\% (9). Penelitian di Rumah Sakit Hasan Sadikin pada tahun 2014 mendapatkan prevalensi malnutrisi pada anak sebesar $28,44 \%$ berdasarkan skrining risiko malnutrisi saat awal masuk rumah sakit (10). Sementara malnutrisi yang terjadi selama anak dirawat di rumah sakit juga menunjukkan variasi yang cukup tinggi. Penelitian yang dilakukan di Bali mendapatkan angka malnutrisi rumah sakit sebesar 24,5\% (11) dan di Makasar sebesar 11,7\% (12). Penelitian di Necker-Enfants Malades Hospital, Paris melaporkan penurunan berat badan lebih dari $2 \%$ terjadi pada $45 \%$ pasien (13).

Anak yang berisiko mengalami malnutrisi rumah sakit dapat dideteksi dengan menggunakan alat skrining yang sederhana dengan validitas dan reliabilitas yang cukup baik $(10,11,13,14)$ serta mudah dilakukan. Hasil skrining akan membantu menentukan apakah pasien perlu asuhan gizi lanjut atau cukup diberikan diet rutin sehari-hari. Tim yang terdiri dari dokter, ahli gizi (dietisien/nutrisionis), perawat, dan penunjang yang lain diantaranya pelayanan instalasi gizi, farmasi, dan administrasi perlu dibentuk dan saling bekerjasama dalam memberikan dukungan nutrisi yang adekuat bagi pasien khususnya yang berisiko mengalami malnutrisi selama dirawat (15-17). Tim dukungan nutrisi ini tentu saja dapat berbeda-beda kebutuhannya tergantung dari besar rumah sakit dan kompleksitas masalah gizi yang dihadapi.

Rumah Sakit Hasan Sadikin sebagai rumah sakit umum pusat (RSUP) rujukan tersier di Provinsi Jawa Barat sekaligus rumah sakit pendidikan telah memiliki semua elemen yang diperlukan dalam tim asuhan nutrisi pediatrik sebagaimana disebutkan sebelumnya. Skrining risiko gangguan gizi dan asuhan gizi lanjut telah dilaksanakan dalam beberapa tahun terakhir sebagai salah satu pelaksanaan pelayanan bagi pasien sesuai dengan standar akreditasi internasional rumah sakit. Namun demikian, belum diperoleh laporan data terbaru mengenai besarnya malnutrisi rumah sakit dan bagaimana pelaksanaan asuhan nutrisi pediatrik untuk memberikan dukungan nutrisi pada anak yang dirawat dalam hal prosedur maupun kerjasama berbagai elemen pemberi dukungan nutrisi. Tujuan penelitian ini adalah untuk mengetahui besarnya kejadian malnutrisi rumah 
sakit di ruang rawat anak Rumah Sakit (RS) Hasan Sadikin Bandung dan mengevaluasi pelaksanaan Asuhan Nutrisi Pediatrik (ANP).

\section{BAHAN DAN METODE}

\section{Desain dan subjek}

Penelitian dilakukan dengan metode potong lintang untuk mengetahui besarnya kejadian malnutrisi rumah sakit. Penelitian kualitatif dilakukan untuk mengetahui pelaksanaan ANP karena tidak dapat dilakukan pengukuran terhadap data yang diperoleh. Penelitian dilakukan di ruang perawatan anak, bangsal infeksi dan non infeksi RS Hasan Sadikin. Penelitian dilaksanakan pada bulan Februari - Maret 2016 yang dimulai sejak lolos kaji etik dari Komite Etik Penelitian Kesehatan (KEPK) Rumah Sakit Umum Pusat Dr. Hasan Sadikin Bandung (No. LB.04.01/A05/EC/438/X/2015) dan telah mendapat izin dari Direktur Rumah Sakit Hasan Sadikin Bandung sesuai peraturan yang berlaku.

Subjek adalah anak yang dirawat di bangsal perawatan anak selama waktu penelitian sedangkan subjek penelitian kualitatif adalah personel yang bekerja di bangsal perawatan anak dan terlibat dalam pemberian dukungan nutrisi bagi pasien serta orang tua/pendamping anak yang dirawat. Subjek untuk penelitian kuantitatif ditentukan berdasarkan kriteria inklusi yaitu pasien anak berusia lebih dari 28 hari dan orangtua bersedia menjadi responden dengan menandatangani informed consent. Sementara kriteria eksklusi adalah pasien yang tidak berhasil didapatkan data penimbangan berat badan saat dipulangkan dan pasien meninggal atau terminal state dengan kondisi do not resuscitate (DNR) pada saat dilakukan penelitian. Berdasarkan rumus besar sampel untuk prevalens tunggal dan proporsi kejadian malnutrisi rumah sakit sebesar 24,5\% (11), serta ketepatan absolut yang dikehendaki $10 \%$, maka didapatkan minimal jumlah sampel sebesar 71 subjek sedangkan pengambilan sampel untuk penelitian kualitatif dilakukan secara purposive sampling $(18,19)$. Populasi penelitian untuk data kualitatif adalah personel yang terlibat dalam pemberian dukungan nutrisi bagi pasien yaitu dokter divisi nutrisi dan penyakit metabolik (NPM), ahli gizi, perawat, ahli farmasi, dan orang tua/pendamping selama anak dirawat.

\section{Pengumpulan dan pengukuran data}

Karakteristiksubjek. Data yang dikumpulkan adalah nama pasien, tanggal masuk, nomor rekam medis, tanggal lahir/usia, jenis kelamin, alamat, diagnosis, data orang tua, skor skrining risiko malnutrisi, status gizi, dan data klinis lain pada saat pasien masuk perawatan. Data tersebut diambil dari catatan rekam medis dan bila diperlukan dilakukan wawancara langsung kepada pendamping pasien.

Skrining risiko malnutrisi. Skrining dilakukan dengan menggunakan The Pediatric Yorkhill Malnutrition Score (PYMS) yang telah dimodifikasi (mPYMS). Terdapat 4 parameter yang digunakan yaitu: 1) Antropometri: berat badan menurut tinggi badan/panjang badan atau menggunakan indeks masa tubuh (IMT) menurut umur yang dibandingkan dengan kurva WHO child growth standard atau WHO child growth reference. Hasil pengukuran antropometri dikategorikan menjadi $\geq-2 \mathrm{SD}$ (skor 0) dan $<-2$ SD (skor 2);2) Kehilangan atau penurunan berat badan akhir-akhir ini dengan kategori tidak ada (skor 0) dan ada (skor 1);3) Asupan makan dalam 1 minggu terakhir dengan kategori makan seperti biasa (skor 0), ada penurunan asupan (skor 1), tidak makan sama sekali atau sangat sedikit (skor 2); 4) Anak sakit berat dengan kategori tidak (skor 0) dan ya (skor 2). Kriteria sakit berat yaitu penyakit yang berisiko terjadi gangguan gizi yang meliputi dirawat di $\mathrm{HCU} / \mathrm{ICU}$, penurunan kesadaran, kegawatan abdomen (perdarahan, ileus, peritonitis, asites masif, tumor intra abdomen besar, post operasi), gangguan pernapasan berat, keganasan dengan komplikasi, gagal jantung, gagal ginjal kronik, gagal hati, diabetes mellitus, atau kondisi sakit berat lain. Skor total risiko malnutrisi disimpulkan sebagai berikut: tanpa risiko (skor 0), risiko rendah skor 1), dan risiko tinggi (skor $\geq 2$ ).

Pengukuran antropometri. Peneliti juga mencatat hasil pemeriksaan antropometri meliputi pengukuran berat badan dan panjang/tinggi badan yang telah rutin dilakukan oleh perawat pada saat pasien masuk pertama kali dirawat dan tercatat dalam buku rekam medis Seluruh perawat yang bekerja di bangsal anak telah dilakukan pelatihan mengenai prosedur pemeriksaan antropometri dan telah distandarisasi oleh peneliti. Selanjutnya, pada saat sebelum pasien dipulangkan dilakukan pemeriksaan berat badan dan pengambilan data klinis lain bila perlu. Hasil pengumpulan data dicatat dalam lembar formulir penelitian. Penimbangan 
saat pasien dipulangkan dilakukan asisten penelitian khusus yang juga adalah perawat yang bekerja di bangsal perawatan anak RS Hasan Sadikin. Asisten penelitian khusus diperlukan karena penimbangan tidak rutin dilakukan pada saat pasien dipulangkan. Pengukuran berat badan menggunakan timbangan merek SECA 813 untuk anak dan SECA 334 baby scale untuk bayi. Tinggi badan/panjang badan diukur dengan menggunakan stadiometer merek SECA 213 untuk anak diatas 2 tahun dan infantometer merek SECA 210 baby length measuring math untuk anak dibawah 2 tahun. Pengukuran lingkar lengan atas menggunakan pita ukur merek SECA 212.

Malnutrisi rumah sakit. Malnutrisi didefinisikan sebagai penurunan berat badan signifikan yang terjadi selama anak dalam perawatan sehingga anak tampak lebih kurus. Penurunan berat badan yang signifikan adalah berkurangnya berat badan lebih dari atau sama dengan $2 \%$ pada anak yang dirawat kurang dari atau sama dengan 7 hari; lebih dari atau sama dengan $5 \%$ pada anak yang dirawat 8-30 hari; dan lebih dari atau sama dengan 10\% pada anak yang dirawat lebih dari 30 hari $(11,12)$.

Data kualitatif. Data dikumpulkan dengan menggunakan focus group discussion (FGD) untuk mengetahui proses asuhan nutrisi bagi pasien. Diskusi dilakukan dengan fokus pertanyaan sebagai berikut: bagaimana prosedur pelaksanaan skrining risiko malnutrisi dan ANP; oleh siapa dan bagaimana pelayanan dukungan nutrisi pasien rawat inap; dan masalah yang dihadapi dalam memberikan dukungan nutrisi. Data yang perlu digali lebih dalam dilanjutkan dengan wawancara terhadap masing-masing subjek. Data dari pendamping pasien diambil dengan melakukan wawancara khususnya dalam hal kepuasan dan keluhan terhadap pelayanan dukungan nutrisi selama anak dirawat yang dilakukan bersamaan pada saat pasien dilakukan penimbangan berat badan sewaktu pasien dipulangkan. Pengambilan data juga dilakukan dengan observasi langsung di lapangan maupun dengan menelaah catatan terintegrasi dari rekam medis.

\section{Analisis data}

Data kuantitatif diolah dengan menggunakan program SPSS versi 21.0. Analisis data kuantitatif berupa statistik deskriptif (persentase) dan analisis bivariat dengan uji beda proporsi data kategorik-kategorik (ChiSquare test) untuk membedakan kelompok karakteristik terhadap kejadian malnutrisi rumah sakit. Hasil bermakna didapatkan jika nilai $\mathrm{p}<0,05$. Data kualitatif yang terkumpul dibaca secara keseluruhan kemudian dilakukan coding sehingga diperoleh tema-tema dan deskripsi. Proses selanjutnya adalah menghubungkan tema-tema dan deskripsi sehingga didapatkan interpretasi dari berbagai tema dan deskripsi $(18,19)$. Hasil analisis penelitian disajikan secara tekstular dan tabular.

\section{HASIL}

\section{Karakteristik subjek}

Selama periode bulan Februari-Maret 2016 jumlah pasien yang dirawat di ruang rawat anak adalah 760 orang sedangkan yang memenuhi kriteria inklusi dan eksklusi sebanyak 111(14,6\%) subjek. Karakteristik anak yang ikut serta dalam penelitian dapat dilihat pada Tabel 1.

Sebanyak 23 (20,7\%) subjek mengalami penurunan berat badan selama perawatan yang 10 (9\%) subjek diantaranya memenuhi kriteria malnutrisi rumah sakit (MRS). Sebanyak 9 subjek mengalami penurunan berat badan tetapi tidak memenuhi kriteria MRS sedangkan 4 subjek lainnya yaitu 2 subjek dengan obesitas dan 2 subjek dengan edema anasarka terjadi penurunan berat badan yang memang diharapkan sehingga tidak termasuk dalam kriteria MRS. Kejadian malnutrisi rumah sakit berdasarkan karakteristik subjek dapat diihat pada Tabel 2. Sebanyak 69 subjek dengan skor skrining risiko malnutrisi lebih dari atau sama dengan 2 , tetapi hanya 20 anak yang dikonsultasikan ke divisi NPM sedangkan 2 subjek lain dengan skor skrining risiko malnutrisi kurang dari 2 juga dikonsultasikan ke divisi NPM.

\section{Asuhan nutrisi pediatrik (ANP) dan tim ANP}

Pelaksanaan ANP di RS Hasan Sadikin adalah sebagai berikut:

Skrining risiko malnutrisi dilaksanakan oleh perawat menggunakan modifikasi The Pediatric Yorkhill Malnutrition Score (PYMS). Kesimpulan hasil skrining dan tindakan yang dilakukan adalah sebagai berikut: skor 0 (tanpa risiko) skrining ulang setelah 1 minggu; 
Tabel 1. Karakteristik subjek $(\mathrm{n}=111)$

\begin{tabular}{lcc}
\hline \multicolumn{1}{c}{ Kelompok } & n & \% \\
\hline Jenis kelamin & & \\
$\quad$ Laki-laki & 59 & 53,2 \\
$\quad$ Perempuan & 52 & 46,8 \\
Kelompok umur & & \\
$\quad 1$ bulan -1 tahun & 25 & 22,5 \\
$>1-5$ tahun & 36 & 32,4 \\
$>5-10$ tahun & 29 & 26,1 \\
$\quad>10$ tahun & 21 & 18,9 \\
Kelompok lama rawat (hari) & & \\
$\quad \leq 7$ & 64 & 57,7 \\
$8-30$ & 45 & 40,5 \\
$\quad>30$ & 2 & 1,8 \\
Kelompok penyakit & & \\
$\quad$ Infeksi & 57 & 5,4 \\
$\quad$ Non infeksi & 54 & 4,6 \\
Status gizi & & \\
$\quad$ Gizi baik & 69 & 62,2 \\
$\quad$ Gizi kurang & 17 & 15,3 \\
Gizi buruk & 23 & 20,7 \\
Gizi lebih & 0 & 0 \\
$\quad$ Obesitas & 2 & 1,8 \\
Skor skrining risiko malnutrisi & & \\
(skor $m P Y M S$ ) & & 62,2 \\
$\quad$ Skor $0-1$ & 42 & \\
Skor 2 atau lebih & 69 & \\
\hline
\end{tabular}

skor 1 (risiko rendah) skrining ulang setelah 3 hari; skor $\geq 2$ dirujuk ke dietisien dan/atau dokter divisi gizi. Pada penelitian ini, hanya 3 dari 42 subjek dengan skor hasil skrining risiko malnutrisi 0-1 yang dilakukan skrining ulang selama perawatan. Dalam pelaksanaan skrining masih didapatkan temuan kesalahan dalam menginterpretasikan skoring terutama oleh staf perawat yang baru.

Asuhan gizi lanjut dilakukan terhadap pasien dengan skor skrining risiko malnutrisi $\geq 2$ dan terutama dilaksanakan oleh dietisien dengan metode proses asuhan gizi terstandar (PAGT) yang ditetapkan dalam standar prosedur operasional asuhan gizi rawat inap. Dokter divisi nutrisi dan penyakit metabolik terlibat dalam ANP hanya jika dikonsultasikan oleh dokter penanggungjawab pelayanan.

Instalasi gizi melayani berbagai bentuk permintaan diet. Preparasi diet enteral dilakukan di pantry khusus yang menyediakan berbagai jenis formula. Instalasi farmasi melayani peracikan nutrisi parenteral di ruangan
Tabel 2. Data kejadian malnutrisi rumah sakit berdasarkan karakteristik subjek

\begin{tabular}{|c|c|c|c|}
\hline Kelompok & $\begin{array}{c}\text { MRS } \\
(\mathrm{n}=10) \\
\mathrm{n}(\%)\end{array}$ & $\begin{array}{c}\text { Tidak MRS } \\
(\mathbf{n}=101) \\
\text { n (\%) } \\
\end{array}$ & $\mathbf{p}^{*}$ \\
\hline \multicolumn{4}{|l|}{ Jenis kelamin } \\
\hline Laki-laki & $2(1,8)$ & $57(51,4)$ & 0,028 \\
\hline Perempuan & $8(7,2)$ & $44(39,6)$ & \\
\hline \multicolumn{4}{|l|}{ Kelompok umur } \\
\hline 1 bulan -1 tahun & $1(0,9)$ & $24(21,6)$ & 0,577 \\
\hline$>1-5$ tahun & $5(4,5)$ & $31(28)$ & \\
\hline$>5-10$ tahun & $2(1,8)$ & $27(24,3)$ & \\
\hline$>10$ tahun & $2(1,8)$ & $19(17.1)$ & \\
\hline \multicolumn{4}{|c|}{ Kelompok lama rawat (hari) } \\
\hline$\leq 7$ & $7(6,3)$ & $57(51,4)$ & 0,674 \\
\hline $8-30$ & $3(2,7)$ & $42(37,8)$ & \\
\hline$>30$ & $0(0)$ & $2(1,8)$ & \\
\hline \multicolumn{4}{|l|}{ Kelompok penyakit } \\
\hline Infeksi & $7(6,3)$ & $50(45)$ & 0,216 \\
\hline Non infeksi & $3(2,7)$ & $51(46)$ & \\
\hline \multicolumn{4}{|l|}{ Status gizi } \\
\hline Gizi baik & $8(7,2)$ & $61(55)$ & 0,666 \\
\hline Gizi kurang & $1(0,9)$ & $16(14,1)$ & \\
\hline Gizi buruk & $1(0,9)$ & $22(19,8)$ & \\
\hline Gizi lebih & $0(0)$ & $0(0)$ & \\
\hline Obesitas & $0(0)$ & $2(1,8)$ & \\
\hline \multicolumn{4}{|c|}{ Skor skrining risiko malnutrisi } \\
\hline Skor 2 atau lebih & $7(6,3)$ & $62(55,9)$ & 0,592 \\
\hline Skor $0-1$ & $3(2,7)$ & $39(35,1)$ & \\
\hline \multicolumn{4}{|l|}{ Konsul ke divisi NPM } \\
\hline Tidak & $9(8,1)$ & $80(72)$ & 0,414 \\
\hline Ya & $1(0,9)$ & $21(19)$ & \\
\hline
\end{tabular}

MRS = malnutrisi rumah sakit; NPM = nutrisi dan penyakit metabolik *uji beda proporsi data kategorik (Chi-Square test)

dengan fasilitas laminar air flow. Nutrisi parenteral lengkap yang siap pakai tersedia (contoh: Kalbiven ${ }^{\circledR}$ ), demikian juga sediaan dengan kandungan komponen tunggal (contoh: Aminosteril ${ }^{\circledR}$, Intralipid $\AA$ ).

Beberapa masalah pokok yang dihadapi dalam pelaksanaan dukungan nutrisi di bangsal rawat anak yaitu: 1) Belum ada pelayanan ANP dari dokter divisi nutrisi dan penyakit metabolik, dietisien, perawat, ahli farmasi, dan tenaga administratif yang bekerja sama sebagai satu tim; 2) Belum ada ketentuan jenis masalah nutrisi yang harus ditangani secara tim; 3) Masih terdapat kekurangan dalam pelaksanaan skrining ulang, monitoring, dan evaluasi karena keterbatasan tenaga, termasuk kekurangan alat penimbangan; 4) Dalam pemberian diet enteral, pelarutan 
dan pemberiannya kepada pasien dilakukan oleh orang tua atau pengasuh lain yang menunggu selama perawatan; 5) Instalasi farmasi belum dapat melayani pemintaan pencampuran nutrisi parenteral total lengkap dalam satu preparat sesuai kebutuhan individual pasien karena alat belum tersedia.

\section{BAHASAN}

\section{Kejadian malnutrisi rumah sakit dan karakteristik subjek}

Sejak pernyataan Butterworth $\mathrm{C}$ dalam artikelnya yang berjudul "The skeleton in the hospital closet" (20) bahwa pentingnya peranan nutrisi dalam proses penyembuhan penyakit dapat luput dari perhatian dokter, kejadian malnutrisi di rumah sakit tetap menjadi perhatian dan merupakan masalah yang harus diwaspadai. Hingga saat ini, berbagai penelitian masih menunjukkan besarnya masalah tersebut dengan prevalensi yang berbeda-beda (11-13).

Kejadian malnutrisi rumah sakit dari hasil penelitian ini yaitu sebesar 9\% tidak jauh berbeda dengan studi di RS Wahidin Sudirohusodo Makassar sebesar 11,7\% (12), tetapi lebih rendah dibandingkan dengan penelitian lainnya yang mendapatkan angka sebesar 24,8\% (11); 30,1\% (21); dan 45\% (13). Hasil penelitian ini mungkin belum dapat menggambarkan prevalensi yang sesungguhnya karena hanya 111(14,6\%) dari 760 pasien yang dirawat selama periode penelitian yang berhasil diikutsertakan dalam penelitian. Perbedaan prevalensi dibandingkan dengan hasil penelitian lain mungkin juga terjadi disebabkan penggunaan kriteria yang berbeda pada masing-masing penelitian.

Data karakteristik yang menjadi faktor risiko terjadinya malnutrisi rumah sakit tidak dapat dilakukan elaborasi lebih lanjut karena diperoleh hasil angka prevalensi yang terlalu kecil. Perlu penelitian dengan jumlah sampel yang lebih besar untuk dapat dilakukan analisis dengan lebih valid dan reliabel. Pada penelitian ini, perbedaan bermakna terlihat pada karakteristik jenis kelamin yaitu anak perempuan lebih tinggi dibandingkan anak laki-laki. Hasil ini berbeda dengan penelitian di RS Wahidin Sudiro Husodo yang menunjukkan bahwa kejadian malnutrisi rumah sakit lebih tinggi pada anak laki-laki (12). Namun demikian, belum ditemukan literatur yang menjelaskan tentang faktor yang mendasari perbedaan tersebut.

Lama perawatan menjadi salah satu penyebab kehilangan berat badan pada pasien di rumah sakit $(12,22,23)$. Pada studi di Makassar, malnutrisi rumah sakit lebih tinggi pada anak yang dirawat lebih dari 7 hari dibandingkan anak yang dirawat 2-7 hari (25\% vs $7 \%$ ) (12). Sementara studi di Brasil menemukan bahwa semakin lama perawatan, maka insiden kehilangan berat badan semakin tinggi yaitu $62,39 \%$ pada anak yang dirawat 10-67 hari (22). Sebaliknya, hasil penelitian ini menunjukkan kejadian malnutrisi rumah sakit yang lebih kecil pada anak yang dirawat lebih dari 7 dibandingkan anak yang dirawat kurang dari atau sama dengan 7 hari (3 vs 7). Hal ini mungkin disebabkan jumlah subjek terbanyak adalah pasien yang dirawat kurang dari atau sama dengan 7 hari (64/111 atau 58\%). Selain itu, kemungkinan pasien yang dirawat lebih lama akan mendapatkan intervensi dukungan nutrisi yang lebih banyak dan intensif sehingga lebih mampu mencegah kejadian malnutrisi selama perawatan.

Status gizi pada saat sebelum masuk rumah sakit berpengaruh terhadap risiko anak untuk mengalami malnutrisi selama proses perawatan $(13,24,25)$. Anak dengan malnutrisi khususnya malnutrisi berat, sering terjadi gangguan saluran cerna berupa diare dan peningkatan inflamasi sistemik yang juga menjadi penyebab tingginya mortalitas (26). Hasil studi di Makassar menunjukkan bahwa kejadian malnutrisi rumah sakit berhubungan dengan kondisi status gizi sebelum anak dirawat, yaitu paling banyak terjadi pada anak dengan status gizi buruk (12). Sementara studi di Italia (24) dan Turki (25) menemukan anak dengan Z-skor indeks massa tubuh atau IMT kurang dari -2 SD mengalami penurunan parameter antropometri ketika dipulangkan dari perawatan. Pada penelitian ini, proporsi terbesar kejadian malnutrisi rumah sakit terdapat pada anak dengan status gizi baik (8 dari 10 anak). Namun, tidak didapatkan hubungan yang bermakna antara status gizi saat masuk dirawat dengan kejadian malnutrisi rumah sakit.

\section{Asuhan nutrisi pediatrik}

Asuhan nutrisi pediatrik dimulai dengan melakukan skrning risiko malnutrisi pada saat awal pasien masuk 
perawatan. Berbagai alat skrining malnutrisi bagi pasien pediatrik telah dikembangkan dan diimplementasikan di berbagai negara $(10,11,27-34)$. Tersedia pula kalkulasi risiko malnutrisi berbasis komputer yaitu The Pediatric Digital Scaled Malnutrition Risk screening Tool (PeDISMART) sehingga memperluas kemampuan mengidentifikasi pasien yang berisiko malnutrisi (33). Berdasarkan berbagai penelitian tersebut, diketahui tingkat sensitivitas dan spesifisitas yang berbeda-beda dari masing-masing alat. Demikian pula terdapat perbedaan dalam hal kepraktisan, sebagai contoh The Screening Tool Risk on Nutritional Status and Growth (STRONGkids) dinyatakan lebih mudah digunakan dalam praktik klinis karena tidak memerlukan pemeriksaan antropometri $(27,30,32)$.

Departemen Ilmu Kesehatan Anak RS Hasan Sadikin mengadopsi metode The Pediatric Yorkhill Malnutrition Score (PYMS) yang telah dimodifikasi. Pemilihan metode ini berdasarkan hasil penelitian (10) yang menunjukkan bahwa PYMS mempunyai sensitivitas 95,32\% dan spesifisitas 76,92\% dibandingkan standar emas Subjective Global Assessment (SGA). Skrining awal risiko malnutrisi telah dilaksanakan secara konsisten meskipun masih ada kendala beberapa kesalahan interpretasi dalam melakukan skoring. Pelatihan yang berkelanjutan perlu dilakukan karena selalu ada pegawai baru di bagian keperawatan yang belum memahami prosedur ANP yang berlaku.

Pelaksanaan skrining ulang masih menjadi masalah karena belum dilakukan dengan konsisten. Terdapat 3 dari 42 subjek dengan hasil skrining skor risiko malnutrisi kurang dari 2 yang tidak dilakukan skrining ulang sehingga mengalami malnutrisi rumah sakit karena tidak mendapatkan tatalaksana asuhan gizi lanjut. Skrining ulang penting dilakukan karena anak dengan hasil pengukuran antropometri subnormal tidak teridentifikasi dengan berbagai alat skrining tersebut di atas (34).

Hasil skrining risiko malnutrisi akan membantu proses identifikasi pasien yang memerlukan asesmen dan intervensi nutrisi yang lebih mendalam. Pada penelitian ini ditemukan 69 anak yang berisiko tinggi terjadi malnutrisi rumah sakit $(62,2 \%)$. Intervensi dapat berupa pemberian suplementasi nutrisi yang akan memberikan manfaat perbaikan klinis, memperpendek lama perawatan, serta mengurangi biaya perawatan (35-38). Dukungan nutrisi khusus disebut sebagai Specialized Nutrition Support (SNS) didefinisikan sebagai pemberian nutrisi oral, enteral atau parenteral dengan tujuan terapetik (39). Berdasarkan penelitian ini diketahui bahwa RS Hasan Sadikin telah menyediakan formula enteral yang cukup lengkap meskipun pelarutan dan pemberian masih harus dilakukan oleh orang tua/pendamping pasien sendiri. Sementara untuk nutrisi parenteral juga telah tersedia secara lengkap dan telah tersedia ruang laminar air flow, tetapi belum dapat melayani peracikan nutrisi parenteral lengkap dalam satu preparat.

Asuhan nutrisi rawat inap yang digunakan RS Hasan Sadikin adalah metode PAGT dengan langkahlangkah yang disingkat sebagai ADIME yaitu asesmen, diagnosis nutrisi, intervensi (rencana dan implementasi) serta monitoring dan evaluasi sebagaimana tercantum dalam standar prosedur operasional (SOP) asuhan gizi rawat inap. Metode ini diadopsi dari rekomendasi American Dietetic Association berupa Nurition Care Process and Model (NCPM) (40). Keempat langkah tersebut diuraikan menggunakan International Dietetics and Nutrition Terminology (IDNT) sebagai bahasa standar (41). Di lain pihak, Unit Kerja Koordinasi Nutrisi dan Penyakit Metabolik Ikatan Dokter Anak Indonesia (UKK NPM IDAI) merekomendasikan Asuhan Nutrisi Pediatrik (ANP) berupa asesmen, menghitung kebutuhan kalori dan protein, menentukan rute dan jenis formula serta monitoring evaluasi dengan menilai acceptability, toleransi, dan efficacy (17).

Berdasarkan kedua rekomendasi di atas, secara esensi terdapat kesamaan dalam melaksanakan langkahlangkah asuhan nutrisi. Kedua metode melaksanakan asesmen sebagai langkah awal. Menghitung kalori, menentukan rute, dan jenis formula pada ANP mempunyai kesamaan dengan rencana intervensi pada PAGT. Perbedaan yang mencolok adalah terdapat penetapan diagnosis nutrisi pada PAGT yang tidak dilakukan pada ANP rekomendasi UKK NPM IDAI.

RS Hasan Sadikin telah melaksanakan ANP dengan melakukan skrining pada setiap pasien rawat inap yang dilanjutkan dengan PAGT terhadap pasien dengan risiko tinggi malnutrisi, tetapi secara keseluruhan tidak dilaksanakan dalam tim yang terkoordinasi. Hal 
ini terlihat dari hasil penelitian yang menunjukkan bahwa pasien yang terskrining berisiko tinggi malnutrisi tidak semua dikonsultasikan ke dokter divisi nutrisi dan penyakit metabolik (NPM) yaitu hanya 20 dari 69 subjek. Pasien yang dikonsultasikan ke dokter NPM berarti akan ditangani secara tim karena terjadi kerjasama antara dokter, perawat, dan dietisien. Tim ANP memiliki peranan penting khususnya untuk tatalaksana pasien yang memerlukan Specialized Nutrition Support (SNS) (38). Tim minimal terdiri dari dokter, dietisien, perawat, dan ahli farmasi dengan peran masing-masing dan berkolaborasi dalam implementasi rencana asuhan nutrisi bagi pasien (42-44). Dokter dalam tim ANP sebaiknya adalah spesialis anak atau dokter senior yang mendalami ilmu gizi (15). Namun, tidak semua rumah sakit memiliki dokter spesialis anak konsultan nutrisi sehingga model ideal tim asuhan nutrisi belum tentu dapat direalisasikan. Meskipun demikian, dokter penanggungjawab pasien dalam menangani masalah nutrisi yang kompleks dapat berkolaborasi (team work) dengan perawat dan dietisien dalam bentuk komunikasi aktif yang tidak hanya melalui catatan perkembangan pasien terintegrasi (CPPT) dan combine care plan (CCP) karena dibutuhkan diskusi yang mendalam terhadap kondisi pasien dan rencana implementasi dukungan nutrisi yang akan diberikan.

Komposisi tim asuhan nutrisi dapat bervariasi tergantung dari tipe institusi, tugas yang menjadi tanggung jawab (kompleksitas masalah nutrisi), ketersediaan staf, dan kemampuan pendanaan. Tugas utama tim asuhan nutrisi diantaranya: 1) Melakukan skrining risiko gangguan nutrisi pada pasien; 2) Mengidentifikasi dan mengimplementasikan tata laksana pada pasien yang memerlukan dukungan nutrisi; 3) Meyakinkan penyediaan tatalaksana dukungan nutrisi yang efektif bagi pasien; 4) Merencanakan pemberian nutrisi di rumah sesudah pasien dipulangkan; 5) Mendidik staf rumah sakit dengan perhatian utama identifikasi dan manajemen problem nutrisi; 6) Melakukan pemantauan dan evaluasi (15). Kualitas kinerja tim asuhan nutrisi akan tergambar dari keberhasilan dalam mencegah kejadian malnutrisi selama pasien dirawat (malnutrisi rumah sakit).

Beberapa aspek telah dimiliki RS Hasan Sadikin untuk dapat memberikan asuhan nutrisi dalam bentuk tim di ruang rawat inap Departemen Ilmu Kesehatan Anak sekalipun masih terdapat kekurangan, diantaranya: 1) Sumber daya manusia: tersedia dokter divisi nutrisi dan penyakit metabolik, dietisien, perawat, dan ahli farmasi, tetapi belum dikoordinasi dalam sebuah tim; 2) Sarana dan prasarana: telah tersedia pelayanan nutrisi oral, enteral, dan parenteral, tetapi masih perlu ditingkatkan dari segi kelengkapan dan kualitas; 3) Alur proses asuhan nutrisi telah tersedia, tetapi peranan dokter divisi nutrisi dan penyakit metabolik belum terintegrasi dalam alur tersebut.

Berdasarkan hasil penelitian ini, dengan mengingat ketersediaan sumber daya manusia, sarana, dan prasarana yang ada maka perlu direkomendasikan usulan alur ANP yang lebih disempurnakan sebagai berikut: 1) Skrining awal yang dilakukan oleh perawat; 2) Pasien dengan hasil skrining kurang dari 2, diberikan diet standar dan dilakukan penimbangan rutin serta skrining ulang sesuai kebutuhan selama perawatan yaitu dalam 3-7 hari atau lebih cepat sesuai dengan masalah klinis dan atau asupan yang dilakukan oleh perawat; 3) Pasien dengan hasil skrining lebih dari atau sama dengan 2, dikonsultasikan ke tim ANP untuk dilakukan asuhan gizi lanjut; 4) Implementasi intervensi dilakukan dengan kolaborasi antara setiap anggota tim dan dokter penanggung jawab pelayanan maupun keluarga/pendamping pasien; 5) Monitoring dan evaluasi dilakukan secara berkelanjutan atau dilakukan reasesmen bila target dukungan nutrisi tidak tercapai; 6) Pertemuan rutin tim ANP misalnya seminggu sekali untuk berdiskusi membahas dan mengkoordinasikan tatalaksana asuhan nutrisi khususnya pada kasus sulit.

Kelebihan dari penelitian ini adalah data diambil dari hasil penimbangan dengan alat yang sama dan data penimbangan saat pulang dilakukan oleh asisten khusus yang tidak melihat data penimbangan awal saat pasien masuk yang tercatat dalam rekam medis. Namun demikian, hal ini juga menjadi kelemahan dari penelitian ini karena idealnya pengukuran antropometri saat awal dan akhir penelitian dilakukan oleh petugas yang sama.

\section{SIMPULAN DAN SARAN}

Malnutrisi selama perawatan atau dengan kata lain malnutrisi rumah sakit sering terjadi pada pasien anak di RS Hasan Sadikin Bandung. Pelaksanaan ANP skrining risiko malnurisi dan proses asuhan gizi lanjut 
telah diimplementasikan dengan cukup baik, tetapi proses monitoring dan evaluasi masih sulit dilaksanakan dengan konsisten. Peningkatan kualitas pelayanan ANP diperlukan untuk dapat menurunkan prevalensi malnutrisi rumah sakit. Kolaborasi tim atau team work yang aktif dan harmonis menjadi kunci keberhasilan dukungan nutrisi selama anak dirawat.

Penelitian lebih lanjut dengan metode longitudinal dan jangka waktu yang panjang perlu dilakukan untuk mengetahui besar prevalensi malnutrisi rumah sakit dengan lebih akurat dan faktor yang mempengaruhinya serta efektivitas kinerja tim asuhan nutrisi. Demikian pula pemilihan model tim serta alur komunikasi maupun prosedur asuhan nutrisi penting untuk ditetapkan dan dilakukan evaluasi sesuai dengan kondisi serta situasi rumah sakit dengan tetap berpegang kepada standar prosedur operasional yang berlaku.

\section{UCAPAN TERIMA KASIH}

Ucapan terima kasih kepada Prof. DR. dr. Damayanti R Syarif, Sp.A(K) dari Fakultas Kedokteran Universitas Indonesia Jakarta dan dr. Gustina Lubis, Sp.A(K) dari Fakultas Kedokteran Universitas Andalas Padang yang telah memberikan kontribusi sebagai penelaah dalam analisis dan penyusunan hasil penelitian.

\section{Pernyataan konflik kepentingan}

Penulis menyatakan tidak ada konflik kepentingan dengan pihak-pihak yang terkait dalam penelitian ini.

\section{RUJUKAN}

1. Barker LA, Gout BS, Crowe TC. Hospital malnutrition: prevalence, identification and impact on patients and the healthcare system. Int J Environ Res Pub Health. 2011;8(2):514-27. doi: 10.3390/ijerph8020514

2. Meilyana M, Djais JTB, Garna H. Status gizi berdasarkan subjective global assessment sebagai faktor yang mempengaruhi lama perawatan pasien rawat inap anak. Sari Pediatri. 2010;12(3):162-7. doi: 10.14238/ sp12.3.2010.162-7

3. Joosten KFM, Hulst JM. Malnutrition in pediatric hospital patients: current issues. Nutrition. 2011;27(2):133-7. doi: 10.1016/j.nut.2010.06.001
4. Mehta NM, Corkins MR, Lyman B, Malone A, Goday PS, Monczka JL, et al. Defining Pediatric malnutrition: a paradigm shift toward etiology-related definitions. J Parenter Enteral Nutr. 2013;37(4):460-81. doi: $10.1177 / 0148607113479972$

5. Morley JE, Thomas DR, G Wilson MG. Cachexia: pathophysiology and clinical relevance. Am J Clin Nutr. 2006;83(4):735-43. doi: 10.1093/ajen/83.4.735

6. Delgado AF, Okay TS, Leone C, Nichols B, Negro GMD, Vaz FAC. Hospital malnutrition and inflammatory response in critically ill children and adolescents admitted to a tertiary intensive care unit. Clinics. 2008;63(3):357-62. doi: 10.1590/s1807-59322008000300012

7. Kac G, Camacho-Dias P, Silva-Coutinho D, SilveiraLopes R, Marins VV-BA, Pinheiro ABV. Length of stay is associated with incidence of in-hospital malnutrition in a group of low-income Brazilian children. Salud Publica Mex 2000;42(5):407-12. doi: 10.1590/s003636342000000500006

8. Marino LV, Goddard E, Workman L. Determining the prevalence of malnutrition in hospitalized paediatric patients. S Afr Med J 2006;96:993-5. doi:

9. Joosten KFM, Hulst JM. Prevalence of malnutrition in pediatric hospital patients. Curr Opin in Ped. 2008;20(5):590-6. doi: 10.1097/MOP.0b013e32830c6ede

10. Wonoputri N, Djais JTB, Rosalina I. Validity of nutritional screening tools for hospitalized children. Journal of Nutrition and Metabolism. 2014;143649:1-6. doi: $10.1155 / 2014 / 143649$

11. Nesa NNM, Sidiartha GL, Prawirohartono EP, Suandi $\mathrm{KG}$. Accuracy of modified simple pediatric nutritional risk score to detect in-hospital malnutrition. Paediatr Indones. 2010;50:305-9. doi: 10.14238/pi50.5.2010.305-9

12. Juliaty A. Malnutrisi rumah sakit pada bangsal anak Rumah Sakit DR. Wahidin Sudirohusodo Makassar. Sari Pediatri. 2013;15(2):65-8. doi: 10.14238/sp15.2.2013.65-8

13. Sermet-Gaudelus I, Poisson-Salomon AS, Colomb V, Brusset MC, Mosser F, Berrier F, et al. Simple pediatric nutritional risk score to identify children at risk of malnutrition. Am J Clin Nutr. 2000;72(1):64-70. doi: 10.1093/ajcn/72.1.64

14. Moeeni V, Day AS. Nutritional risk screening tools in hospitalised children. International Journal of Child Health and Nutrition 2012;1:39-43. doi: 10.6000/19294247.2012.01.01.05

15. Agostoni C, Axelson I, Colomb V, Goulet O, Koletzko $\mathrm{B}$, Michaelsen KF, et al. The need for nutrition support teams in pediatric units: a commentary by the ESPGHAN Committee on Nutrition. J Pediatr Gastroenterol Nutr. 2005 Jul;41(1):8-11. doi: 10.1097/01.mpg.0000163735.92142.87 
16. Departemen Kesehatan Republik Indonesia. Skrining malnutrisi pada anak yang dirawat di rumah Sakit. Jakarta: Depkes RI; 2007.

17. Unit Kerja Koordinasi Nutrisi dan Penyakit Metabolik. Asuhan nutrisi pediatrik. Rekomendasi Ikatan Dokter Anak Indonesia. Jakarta; UKK NPM IDAI: 2011.

18. Sugiyono. Memahami penelitian kualitatif. Cetakan kesembilan. Bandung: Penerbit Alfabeta; 2014.

19. Creswell JW. Research design. Pendekatan kualitatif, kuantitatif, dan mixed. edisi ketiga, cetakan keempat. Yogyakarta: Penerbit Pustaka Pelajar; 2014.

20. Butterworth $\mathrm{C}$. The skeleton in the hospital closet. Nutrition Today 1974;9(2):4-8.

21. Sidiartha IGL. Insidens malnutrisi pada anak balita yang menjalani rawat inap di Rumah Sakit Umum Pusat Sanglah Denpasar. Sari Pediatri. 2008;9(6):381-5. doi: 10.14238/ sp9.6.2008.381-85

22. Rocha GA, Rocha EJM, Martins CV. The effects of hospitalization on the nutritional status of children. $\mathrm{J}$ Pediatr. 2006;82(1):70-4. doi: 10.2223/JPED.1440

23. Pichler J, Hill SM, Shaw V, Lucas A. Prevalence of undernutrition during hospitalisation in a children's hospital: what happens during admission? Eur J of Clin Nutr. 2014;68(6):730-5. doi: 10.1038/ejcn.2014.21

24. Campanozzi A, Russo M, Catucci A, Rutigliano I, Canestrino G, Romondia A, et al. Hospital-acquired malnutrition in children with mild clinical conditions. Nutrition. 2009;25(5):540-7. doi: 10.1016/j.nut.2008.11.026

25. Oztürk Y, Büyükgebiz B, Arslan N, Ellidokuz H. Effects of hospital stay on nutritional anthropometric data in Turkish children. J Trop Pediatr. 2003;49(3):189-90. doi: 10.1093/ tropej/49.3.189

26. Attia S, Versloot CJ, Voskuij1 W, van Vliet SJ, Di Giovanni $\mathrm{V}$, Zhang L, et al. Mortality in children with complicated severe acute malnutrition is related to intestinal and systemic inflammation: an observational cohort study. Am J Clin Nutr. 2016;104(5):1441-9. doi: 10.3945/ ajcn. 116.130518

27. Hulst JM, Zwart H, Hop WC, Joosten KF. Dutch national survey to test the STRONGkids nutritional risk screening tool in hospitalized children. Clin Nutr. 2010;29(1):106-11. doi: 10.1016/j.clnu.2009.07.006

28. Gerasimidis K, Keane O, Macleod I, Flynn DM, Wright CM. A four-stage evaluation of the Paediatric Yorkhill Malnutrition Score in a tertiary paediatric hospital and a district general hospital. Br J Nutr. 2010;104(5):751-6. doi: 10.1017/S0007114510001121

29. Gerasimidis K, Macleod I, Maclean A, Buchanan E, McGrogan P, McAuley M, et al. Performance of the novel Paediatric Yorkhill Malnutrition Score (PYMS) in hospital practice. Clin Nutr. 2011;30(4):430-5. doi: 10.1016/j.clnu.2011.01.015
30. Spagnuolo MI, Liguoro I, Chiatto F, Mambretti D, Guarino A. Application of a score system to evaluate the risk of malnutrition in a multiple hospital setting. Ital J Pediatr. 2013;39:81. doi: 10.1186/1824-7288-39-81

31. White M, Lawson K, Ramsey R, Dennis N, Hutchinson $\mathrm{Z}$, Soh XY, et al. Simple nutrition screening tool for pediatric inpatients. J Parenter Enteral Nutr 2016;40(3):392-8. doi: 10.1177/0148607114544321

32. Teixeira AF, Viana KD. Nutritional screening in hospitalized pediatric patients: a systematic review. J Pediatr (Rio J). 2016;92(4):343-52. doi: 10.1016/j.jped.2015.08.011

33. Karagiozoglou-Lampoudi T, Daskalou E, Lampoudis D, Apostolou A, Agakidis C. Computer-based malnutrition risk calculation may enhance the ability to identify pediatric patients at malnutrition-related risk for unfavorable outcome. J Parenter Enteral Nutr 2015;39(4):418-25. doi: 10.1177/0148607114529161

34. Chourdakis M, Hecht C, Gerasimidis K, Joosten KF, Karagiozoglou-Lampoudi T, Koetse HA, et al. Malnutrition risk in hospitalized children: use of 3 screening tools in a large European population. Am J Clin Nutr. 2016;103(5):1301-10. doi: 10.3945/ajen.115.110700

35. Gallagher-Allred CR, Voss AC, Finn SC, McCamish MA. Malnutrition and clinical outcomes: the case for medical nutrition therapy. J Am Diet Assoc. 1996;96(4):361-6. doi: 10.1016/s0002-8223(96)00099-5

36. Somanchi M, Tao X, Mullin GE. The facilitated early enteral and dietary management effectiveness trial in hospitalized patients with malnutrition. J Parenter Enteral Nutr. 2011;35(2):209-16. doi: 10.1177/0148607110392234

37. Starke J, Schneide H, Alteheld B, Stehle P, Meier R. Short-term individual nutritional care as part of routine clinical setting improves outcome and quality of life in malnourished medical patients. Clin Nutr. 2011;30(2):194201. doi: 10.1016/j.clnu.2010.07.021

38. Elia M, Normand C, Norman K, Laviano A. A systematic review of the cost and cost effectiveness of using standard oral nutritional supplements in the hospital setting. Clin Nutr 2016;35(2):370-80. doi: 10.1016/j.clnu.2015.05.010

39. ASPEN Board of Directors and the Clinical Guidelines Task Force. Guidelines for the use of parenteral and enteral nutrition in adult and pediatric patients. J Parenter Eneral Nutr 2002;26(1 Supp): 1SA-138SA.

40. Writing Group of the Nutrition Care Process/Standardized Language Committee. Nutrition care process and model part I: the 2008 update. J Am Diet Assoc. 2008; 108(7):11137. doi: 10.1016/j.jada.2008.04.027

41. Writing Group of the Nutrition Care Process/Standardized Language Committee. Nutrition care process part II: using the International Dietetics and Nutrition Terminology to document the nutrition care process. J Am Diet Assoc. 2008;108(8):1287-93. doi: 10.1016/j.jada.2008.06.368 
42. ESPGHAN. Organisational aspects of hospital PN. J Pediatr Gastroenterol Nutr. 2005;41:S63-9. doi: 10.1097/01.mpg.0000181850.46994.b2

43. Tappenden KA, Quatrara B, Parkhurst ML, Malone AM, Fanjiang G, Ziegler TR. Critical role of nutrition in improving quality of care: an interdisciplinary call to action to address adult hospital malnutrition. J Parenter Enteral
Nutr. 2013;37(4):482-97. doi: 10.1177/0148607113484066

44. Guenter P, Jensen G, Patel V, Miller S, Mogensen KM, DiMaria-Ghalili RA, et al. Addressing disease-related malnutrition in hospitalized patients: a call for a national goal. Jt Comm J Qual Patient Saf. 2015;41(10):469-73. doi: 10.1016/s1553-7250(15)41061-x 